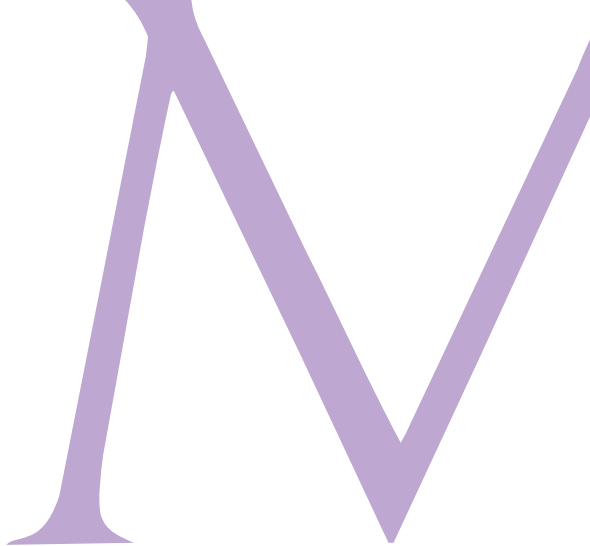

sofridos. "No dia seguinte, internet e coleta de lixo reciclável ainda não estavam normalizadas. Mas casas e ruas estavam sendolimpase, como muitos moradores possuem seguro, móveis, carpetes e outros utensílios danificados foram descartados e substituídos por novos. As ruas na segunda-feira amanheceram com muito material para ser recolhido, o que foi feito de forma bem rápida", explica.

Situação bem diferente enfrenta a Geórgia, pequeno país situado no Cáucaso, na fronteira entre a Europa e a Ásia. Ocupa uma área um pouco maior do que a do estado da Paraíba e possui uma população de cerca de 4,3 milhões de pessoas, das quais $20 \%$ vivem em Tbilisi. Com economia frágil, a Geórgia precisará de ajuda externa para se recuperar dos impactos causados pelas inundações.

Os extremos climáticos afetam mais profundamente os países menos desenvolvidos porque possuem menor resiliência social e econômica para fazer frente aos choques causados pelos extremos. Nobre afirma que "uma das políticas públicas mais importantes de adaptação às mudanças climáticas é aumentar a resiliência quanto aos extremos climáticos". E este, apesar de longo, é o caminho que precisamos percorrer em um mundo tão desigual quanto o nosso.

\section{MANIPULAÇÃO GENÉTICA}

\section{Prevenção de doenças mitocondriais já é realidade no Reino Unido}

Cegueira, fraqueza muscular, falência do coração e do fígado, diabetes, são algumas doenças que podem ser transmitidas a uma criança por mitocôndrias defeituosas. Evitá-las é o principal objetivo de um projeto de lei aprovado neste ano no Reino Unido, primeiro país a legalizar uma técnica de manipulação genética que permite gerar embriões que carregam o DNA de duas mulheres e de um homem, o que pode ser interpretado como um caso de tripaternidade.

Quando é detectado algum tipo de má formação ou alteração mitocondrial, o núcleo saudável de um óvulo de uma mulher que deseja ter filhos é retirado e implantado em outro óvulo (sem o núcleo) de uma doadora que tenha mitocôndrias saudáveis. Depois, esse "novo" óvulo será fertilizado com o esperma do pai biológico. “Uma vez que as mitocôndrias contêm seu próprio material genético (o DNA mitocondrial), o embrião produzido mediante essa tecnologia seria portador de DNA de três pessoas: o casal responsável por conceber o embrião contribuiria com o DNA nuclear enquanto uma terceira pessoa contribuiria com o DNA mitocondrial", explica Marcos Chiaratti, professor do Departamento de Genética e Evolução, da Universidade Federal de São Carlos (UFSCar).

\section{INFERTILIDADE EM MULHERES}

Segundo o pesquisador, a terapia de substituição de mitocôndrias tem sido proposta para tratar a infertilidade de mulheres, principalmente aquelas de idade mais avançada (acima de 35 anos), que não respondem a outros tratamentos comumente utilizados em clínicas de reprodução assistida. “Uma vez que há uma forte associação entre envelhecimento e o declínio da função mitocondrial, a mitocôndria tem sido apontada como um dos principais fatores responsáveis pelo declínio da fertilidade em mulheres devido à idade. Se confirmada a hipótese, a introdução de mitocôndrias doadas por uma mulher mais jovem teria o potencial de recuperar a fertilidade dos óvulos da mulher mais velha", afirma Chiaratti. São os genes nucleares os principais responsáveis por determinarem o fenótipo (características físicas) do indivíduo. "É esperado que a criança gerada por esta tecnologia 
